Opinion

Copyright (C) All rights are reserved by Manuel Mateos de Vicente

\title{
Forest Fires \\ The Disaster in California and Spain
}

\author{
Manuel Mateos de Vicente* \\ Iowa State University, USA
}

*Corresponding author: Manuel Mateos de Vicente, Department of Anthropology,

Iowa State University, Madrid, USA.

Received Date: March 01, 2019

Published Date: March 26, 2019

\section{Opinion}

Before dealing with such a problem the background of the author will be mentioned. My preparation includes a variety of subjects related to forest in subjects as follow:

- $\quad$ Soil Physics and Soil Chemistry

- Biophysical Chemistry

- $\quad$ Soil and Water Conservation

- Molecular structure of the different clays

To develop a land taking into account the different soil horizons, plantations and fertilizes.

Visiting forests in Spain and other countries, even Tasmania where I saw the best trees integration with as great variety.

What happens when a land is planted with pine trees? There are families whose way of living is destroyed. They cannot have beehives and have to sell the goats herd. Solution: To burn the pine forest.

Wolves are proliferating and killing cows and calves by dozens. Solution: To burn patches where the wolves live.

What to do when a tree is rotten at the base? If we cut it, we face an important fine. We individuals are stupid, and we have to call the government to send a forester to certify the need to cut such a dangerous tree, which may take two months if it happens in a village 30 or more miles away from the capital city.

The Government of Spain has planted forest with trees not autochthonous from Spain, such as eucalyptus, a tree that kills any other plantation with its leaves composed of chemicals that kill other species. The authorities lack needed information to explain that eucalyptus do not impoverish the soil on a permanent basis.
Fire-break lanes are generally too narrow and sometimes separated many miles. Some of them are not taken care of.

The forests should be taken care such as trimming branches and removing from the soil surface the shrubs which have fallen or ground and could easily burn Figure 1).
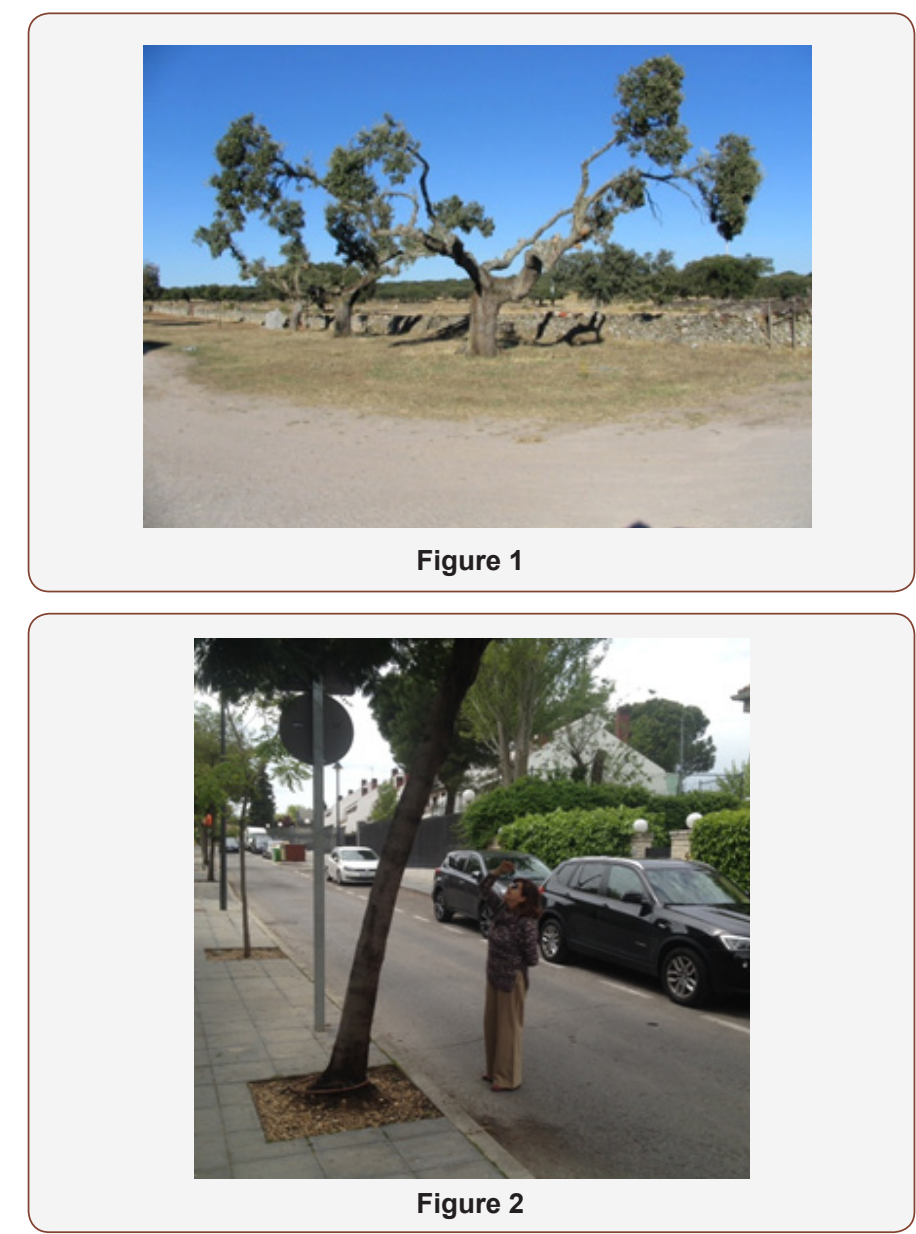
Way of trimming oaks in the part of Spain where I was born which was developed for the need to use the fruit to feed pigs. It is now criticized, and opposed, by technical persons formed in the universities (Figure 2).

Some trees planted in the street where I live are imported from lands of desert-like climate. A daily irrigation made the trunk to rotten and some of them have caused deaths when they fell. So far 12 trees have fallen in the last year, only 5 years after planted (Figure 3).

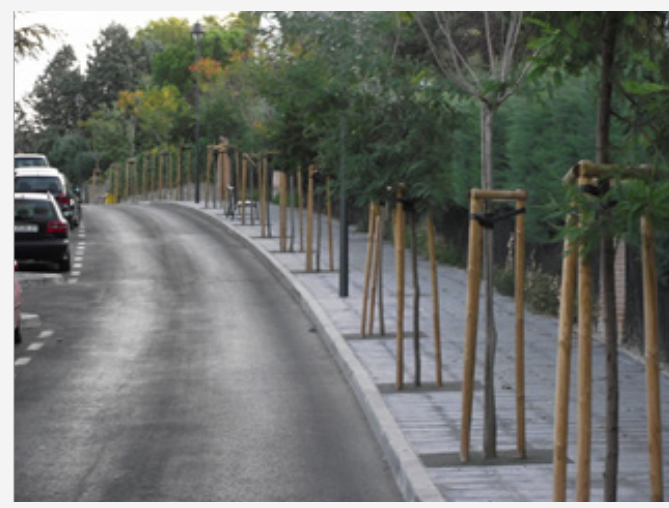

Figure 3

In my street, the Project Engineer did not know that trees grow upwards. Life Member, American Association for the Advancement of Science.

Life Member, Institute of Transportation Engineers

Life Member, Iowa Academy of Sciences

Life Member, Nacional Geographic Society

Life Member, Fellow grade, American Society of Civil Engineers

Life Member, Soil and Water Conservation Society

Life Member, Sigma Xi, Honorary Research Society

Member since 1959: Transportation Research Board, National Academy of Sciences, USA
Honorary Member, Asociación Española de la Carretera

Member, Benefactor, Real Academia Española

Special Member ADENA (WWF)

Listed in Who's Who in the World, etc. - ABI "Man of the Year 2012" - Several awards in Spain

\section{Dedication Manuel Mateos De Vicente of Social Impact}

- $\quad$ Traffic: Over 300 publication on traffic safety - Hundreds of proposals were accepted. Given a medal

- Education: 20 publications on university studies in Spain

- Ecology: 100 publications on the use of waste as construction materials

- Materials: Discovered new cements $=$ less $\mathrm{CO}_{2}$. The architecture based on improved earth.

- Philology: Several analyses of Spanish language on different subjects

- Literature: Poems in three languages, "Ceriballos", "Feelings", "Sensations".

- $\quad$ Social Anthropology: Establish an industry in a backward village; Rural population in Iraq and in Mongolia. A book on Health

- Hydraulics: Ten books on conduits and valves: www. bellisco.com - 100 publications in total

- Soil Mechanics: 100 publications. Nine books, six of them in English, on my research.

\section{Acknowledgement}

None.

\section{Conflict of Interest}

No conflict of interest. 